\title{
Transgenic overexpression of neuromedin $U$ promotes leanness and hypophagia in mice
}

\author{
T J Kowalski, B D Spar, L Markowitz ${ }^{1}$, M Maguire", A Golovko', \\ S Yang ${ }^{1}$, C Farley, J A Cook, G Tetzloff, L Hoos, R A Del \\ Vecchio $^{2}$, T M Kazdoba², M F McCool ${ }^{2}$, J J Hwa, L A Hyde², \\ H Davis, G Vassileva ${ }^{1}$, J A Hedrick' ${ }^{1}$ and E L Gustafson ${ }^{1}$
}

Department of CV/Metabolic Diseases, 'Department of Discovery Technologies and ${ }^{2}$ Department of CNS Research, Schering-Plough Research Institute, Kenilworth, New Jersey 07033, USA

(Requests for offprints should be addressed to T J Kowalski; Email: timothy.kowalski@spcorp.com)

\begin{abstract}
Recent work has shown that neuromedin $\mathrm{U}(\mathrm{NmU})$, a peptide initially identified as a smooth muscle contractor, may play a role in regulating food intake and energy homeostasis. To further evaluate this putative function, we measured food intake, body weight, energy expenditure and glucose homeostasis in transgenic mice that ubiquitously overexpress murine proNmU. $\mathrm{NmU}$ transgenic mice were lighter and had less somatic and liver fat, were hypophagic, and had improved insulin sensitivity as judged by an intraperitoneal insulin tolerance test. Transgenic mice had higher levels of hypothalamic NPY, POMC and $\mathrm{MCH}$ mRNA. There was no difference in $\mathrm{O}_{2}$ consumption between genotypes; however, $\mathrm{NmU}$ transgenic mice
\end{abstract}

displayed a modest increase in respiratory quotient during food deprivation and refeeding. There were no behavioral disturbances in the $\mathrm{NmU}$ transgenic mice that could account for the results (e.g. changes in locomotor activity). When placed on a high-fat diet, transgenic mice remained lighter than wild-type mice and ate less, but gained weight at a rate similar to wild-type mice. Despite the increased weight gain with high-fat feeding, glucose tolerance was significantly improved in the transgenic mice. These findings support the hypothesized role of $\mathrm{NmU}$ as an endogenous anorexigenic peptide.

Journal of Endocrinology (2005) 185, 151-164

\section{Introduction}

Neuromedin $\mathrm{U}(\mathrm{NmU})$ is a peptide that was first isolated from porcine spinal cord (Minamino et al. 1985a,b). Two active peptides were identified in this work: an amidated 25-amino-acid peptide (NmU-25) that is generated by enzymatic cleavage at the C-terminal region of a 174amino-acid precursor (Lo et al. 1992) and an 8-amino-acid cleavage product of NmU-25 (NmU-8) (Minamino et al. 1985b), both of which possess smooth muscle contractile activity (Minamino et al. 1985a,b). NmU cDNAs from dog, rabbit, frog, rat and human have been cloned (Domin et al. 1989, Kage et al. 1991, O'Harte et al. 1991, Lo et al. 1992, Austin et al. 1995) and demonstrate a strong amino-acid sequence homology. In particular, it has been shown that the C-terminal heptapeptide core of $\mathrm{NmU}$ (FLFRPRN-NH $\mathrm{N}_{2}$ ) constitutes a conserved domain that is sufficient for biologic activity (Hashimoto et al. 1991).

Expression analysis in mammalian species has shown that $\mathrm{NmU}$ precursor mRNA is widely distributed but is particularly high in the upper gastrointestinal (GI) tract and the central nervous system (CNS). In human tissue,
$\mathrm{NmU}$ mRNA is found in the intestine, stomach, pituitary gland and several brain regions, including hypothalamus, locus coeruleus, thalamus, medulla and substantia nigra; it is also found in lymphoid cells (Sumi et al. 1987, Austin et al. 1995, Hedrick et al. 2000, Raddatz et al. 2000). A similar expression pattern is observed in rat (Domin et al. 1987, Fujii et al. 2000) and mouse (Funes et al. 2002). Immunohistochemical analysis of rat tissue displays a protein pattern consistent with mRNA expression, with NmU-like immunoreactivity found in the submucosal and myenteric ganglion cells of the small intestine as well as several brain regions (Honzawa et al. 1987, 1990, Augood et al. 1988).

Two human $\mathrm{NmU}$ receptors have been identified (Hedrick et al. 2000, Shan et al. 2000). One receptor is expressed predominantly in the periphery (NmU-R1), notably in the small intestine, pancreas, stomach, testis, liver, kidney and immune cells (Hedrick et al. 2000, Howard et al. 2000, Raddatz et al. 2000), with little to no expression in the CNS. The second receptor (NmU-R2) is expressed predominantly in the CNS, including the paraventricular nucleus (PVN) of the hypothalamus, the 
wall of the third ventricle in the hypothalamus, the CA1 region of the hippocampus and the spinal cord, but it is also detected in testis, lung, kidney and thyroid (Howard et al. 2000, Raddatz et al. 2000, Shan et al. 2000). Likewise, two $\mathrm{NmU}$ receptors have been identified in the mouse and display an expression pattern and pharmacology similar to the human receptors (Funes et al. 2002).

In addition to the effects on smooth muscle contraction, several biologic activities have since been reported for $\mathrm{NmU}$ (reviewed in (Brighton et al. 2004). These include regulation of blood pressure, ion transport in the gut, splanchnic blood flow and adrenocortical function (Minamino et al. 1985b, Brown \& Quito 1988, Gardiner et al. 1990, Malendowicz et al. 1994). Recently, NmU has been implicated in the control of energy homeostasis. Specifically, intracerebroventricular (i.c.v.) administration of $\mathrm{NmU}$ to rats and mice suppresses starvation-induced feeding, and increases locomotor activity, grooming and rectal temperature (Howard et al. 2000, Kojima et al. 2000, Nakazato et al. 2000). Similar effects have been seen with intra-PVN administration (Wren et al. 2002). This is accompanied by increased c-Fos immunoreactivity in the PVN, and supraoptic and parabrachial nuclei (Niimi et al. 2001). Furthermore, i.c.v. administration of anti-NmU antiserum increases feeding in rats (Kojima et al. 2000). $\mathrm{NmU}$ is expressed in the ventromedial hypothalamic area and the nucleus tractis solitaris of the rat, and its expression is decreased with starvation or leptin receptor deficiency (Ivanov et al. 2002), consistent with its postulated role as an endogenous anorexigenic neuropeptide. Recent work has shown that mice lacking the gene encoding $\mathrm{NmU}$ develop an obese phenotype characterized by hyperphagia, hypoactivity, hypothermia and decreased energy expenditure (Hanada et al. 2004), consistent with pharmacologic data.

To further explore the role of $\mathrm{NmU}$ in body weight regulation, we evaluated body composition, food intake, energy expenditure and glucose homeostasis in mice that broadly express a transgene encoding murine proNmU. The results of this analysis show that $\mathrm{NmU}$ transgenic $(\mathrm{Tg})$ mice maintained on a chow diet are leaner than wild-type mice and hypophagic, and have increased insulin sensitivity, while $\mathrm{Tg}$ mice maintained on a high-fat diet are leaner and have an improved glucose tolerance.

\section{Materials and Methods}

\section{Animal care and maintenance}

Mice were group housed in ventilated cages and given chow (PicoLab; $11 \%$ of calories from fat) and water ad libitum. Prior to study at 10-24 weeks of age, mice were individually housed in polycarbonate cages and fed chow, a semipurified low-fat diet ( $10 \%$ of calories from fat), or a semipurified high-fat diet ( $45 \%$ of calories from fat; D12450B and D12451 respectively; Research Diets, New Brunswick, NJ, USA), and had ad libitum access to water.
They were maintained under a $12 \mathrm{~h} / 12 \mathrm{~h}$ light/dark cycle at a temperature of $22{ }^{\circ} \mathrm{C}$.

Three separate cohorts of male mice were used for the feeding and indirect calorimetry studies reported. For experiments in which animals were studied under chowfed conditions, daily food intake was measured for 24 consecutive days in 24-32-week-old mice $(n=17-20$ per group). Animals used in studies examining diet-induced obesity ( $n=7-8$ per group) were transferred from chow to a low-fat diet at 10-13 weeks of age, and food intake and body weight were monitored weekly for 5 weeks, after which time the mice were transferred to a high-fat diet. Daily food intake and body weight was monitored for 20 consecutive days and periodically thereafter for 11 weeks. Mice used for indirect calorimetry studies were maintained on chow and studied at 27-28 weeks of age $(n=8$ per group).

At the end of each study, animals were killed by $\mathrm{CO}_{2}$ asphyxiation, and tissues for RNA isolation were dissected and placed into RNA Later (Ambion, Austin, TX, USA) for $48-96 \mathrm{~h}$ at $4{ }^{\circ} \mathrm{C}$ and frozen at $-80{ }^{\circ} \mathrm{C}$ until analysis. All studies were conducted in an American Association for Laboratory Animal Care accredited facility, according to protocols approved by the Schering-Plough Research Institute Animal Care and Use Committee. The procedures were performed in accordance with the principles and guidelines established by the National Institutes of Health for the care and use of laboratory animals.

\section{Transgene construction and generation of $\mathrm{Tg}$ mice}

Generation of $\mathrm{Tg}$ mice The entire coding sequence of the mouse NmU gene (GenBank AF203444) was amplified by PCR primers containing a Kozak consensus sequence and subcloned into the EcoRI site of a vector containing the human CMV enhancer/chicken $\beta$-actin promoter expression cassette graciously provided by Dr M. Okabe, Osaka University (Okabe et al. 1997). The transgene was isolated from the plasmid by restriction digest with BamHI and SalI and further purified from the vector DNA by sucrose gradient centrifugation, as previously described (Mann \& McMahon 1993). Fractions containing the transgene were pooled, concentrated by Microcon-100 filters (Millipore, Billerica, MA, USA), and washed five times with microinjection buffer $(5 \mathrm{mM}$ Tris- $\mathrm{HCl}(\mathrm{pH}$ $7 \cdot 4), 5 \mathrm{mM} \mathrm{NaCl}$ and $0.1 \mathrm{mM}$ EDTA). Transgene DNA was resuspended in microinjection buffer to a final concentration of $1-5 \mathrm{ng} / \mu \mathrm{l}$, microinjected into eggs ([C57BL/6J x DBA/2] F2; Jackson Laboratory, Bar Harbor, ME, USA), and transferred into oviducts of ICR foster mothers (Charles River Laboratories, Wilmington, MA, USA), according to published procedures (Hogan 1986). At 10 days after birth, a piece of tail from the resulting animals was clipped for DNA analysis. Identification of $\mathrm{Tg}$ mice was accomplished by PCR amplification 
of mouse tail DNA (Lira et al. 1990), using the following recognition primers for the transgene (polyA): forward, $5^{\prime}$-agtgtgcaggctgcctatcagaatgt- $3^{\prime}$; reverse, 5'-tctgatgttttaaa tgatttgccctcc- $3^{\prime}$. The endogenous LDL gene, used as an internal control, was amplified with the following primers: $5^{\prime}$-accccaagacgtgctcccaggatga-3' (forward) and $5^{\prime}$-cgcagtg ctcctcatctgacttgt- $3^{\prime}$ (reverse). PCR conditions were as follows: $94{ }^{\circ} \mathrm{C}, 30 \mathrm{~s} ; 60{ }^{\circ} \mathrm{C}, 30 \mathrm{~s} ; 70{ }^{\circ} \mathrm{C}, 60 \mathrm{~s}$ for 30 cycles. $\mathrm{Tg}$ animals were kept under pathogen-free conditions.

\section{Quantitation of gene expression}

Tissue preparation Mice were killed with $\mathrm{CO}_{2}$, and tissues removed and placed in RNAlater (Ambion) until processing. The static levels of $\mathrm{NmU}$ and the two $\mathrm{NmU}$ receptors were examined in 8-week-old mice under chow-fed conditions, with a total of 10 tissues taken from two NmU Tg mice and two wild-type littermates. To determine the effect of the transgene on $\mathrm{NmU}$ and other hypothalamic obesity-related genes, we collected hypothalami from eight $\mathrm{Tg}$ and nine wild-type, chow-fed, 30week-old mice and used them for quantitative PCR analysis. Total RNA was isolated from the tissues with TRI-reagent (MRC, Cincinnati, OH, USA), or a commercial kit (RNeasy Lipid Kit; Qiagen) and tested for quality and quantity with an Agilent 2100 Bioanalyzer (Waldbroun, Germany). In addition, three mice of each genotype were perfused with $4 \%$ paraformaldehyde; their brains were removed and stored in 30\% sucrose to be used for the in situ hybridization studies described below.

Quantitative PCR Taqman primers and probes (Table 1) were designed with Primer Express software (ABI, Foster City, CA, USA), and purchased from ABI. The quantitative PCR was carried out with an ABI Prism 5700 sequence detection system, using the components from the Platinum Quantitative RT-PCR One-Step Kit (Invitrogen, Carlsbad, CA, USA). The final concentrations of the primers and probe in the PCR reactions were 200 and $100 \mathrm{nM}$ respectively, and each $12.5 \mu \mathrm{l}$ PCR reaction contained $5.0 \mu \mathrm{l}(5 \mathrm{ng})$ total RNA prepared as described above. The RT-PCR reactions for all genes were performed according to the following protocol: one 30-min cycle at $48{ }^{\circ} \mathrm{C}$, followed by one 20 -min cycle at $95^{\circ} \mathrm{C}$, followed by 40 cycles at $95^{\circ} \mathrm{C}$ for $15 \mathrm{~s}$ and $60{ }^{\circ} \mathrm{C}$ for $1 \mathrm{~min}$. Separate plates of the same RNAs were used to quantitate 18S RNA as an internal control for RNA quality. The PCR data were quantitated on standard curves generated with serial dilutions of gene-specific PCR products encompassing the amplicons generated by the quantitative PCR primers. The RNAs from the four mice (two Tg, two wild-type) used to assess $\mathrm{NmU}$ expression in several tissues were run separately, in duplicate, and the mean value for each mouse was calculated. The RNAs from the hypothalamus of the chow-fed mice of each genotype were run separately, in quadruplicate, for each neuropeptide, and results were expressed as the mean \pm S.E. of $f g /$ reaction.

In situ hybridization Forty-five-mer sense and antisense oligonucleotide probes were designed, and the sequences used were as follows: sense, 5'-TCA AAG CAG AAT ACC AGA GTC CTT CCG TGG GTC AAA GTA AGG GAT-3'; antisense, 5-ATC CCT TAC TTT GAC CCA CGG AAG GAC TCT GGT ATT CTG CTT TGA-3'. The probes were $3^{\prime}$-end labeled with ${ }^{35}$ S-dATP, using TdT (Stratagene, La Jolla, CA, USA). Coronal sections through the mouse brain were cut at $40 \mu \mathrm{m}$ with a cryostat, and the tissue sections hybridized, washed and exposed to Kodak Biomax autoradiographic film according to previously published protocols (Gustafson et al. 1997, Kowalski et al. 1998).

\section{Assessment of $\mathrm{NmU}$ peptide production}

Spleens from an 8-week-old $\mathrm{NmU} \mathrm{Tg} \mathrm{mouse} \mathrm{and} \mathrm{a}$ wild-type littermate were aseptically harvested, finely minced, and placed into culture for 5 days $(0.5 \mathrm{ml}$ serum-free RPMI). Conditioned medium was subsequently collected, clarified by centrifugation, and assayed for bioactivity against NmU-R2-transfected HEK293 cells with the fluorescent imaging plate reader (Molecular Devices, Sunnyvale, CA, USA), as previously described (Shan et al. 2000). Spleens harvested from non-Tg littermates provided media for a negative control, as did nonconditioned medium.

\section{Tissue histology}

A wild-type and an $\mathrm{NmU}$ Tg mouse were killed by $\mathrm{CO}_{2}$ asphyxiation, and several tissues were dissected and placed into 10\% neutral buffered formalin. Representative sections of each tissue were embedded in paraffin and sectioned on a Zeiss HM 330 microtome at $5 \mu \mathrm{M}$ and stained with standard hematoxylin and eosin. Tissue histology was assessed by an experienced pathologist blinded to the genotype of the animals under examination.

\section{Measurement of adiposity and body composition}

At the end of the chow and high-fat feeding experiments, animals were killed by $\mathrm{CO}_{2}$ asphyxiation and bled by cardiac puncture for measurement of plasma metabolites and hormones (see below). The nasoanal length was measured, and the right epididymal, retroperitoneal and inguinal adipose depots and the mesenteric adipose depot were dissected and weighed. The total dissectible adipose tissue weight of each animal was defined as the sum of [(right epididymal, retroperitoneal and inguinal depots) 2] + (mesenteric depot). In a separate cohort of mice used for indirect calorimetry (see below), a nuclear magnetic 

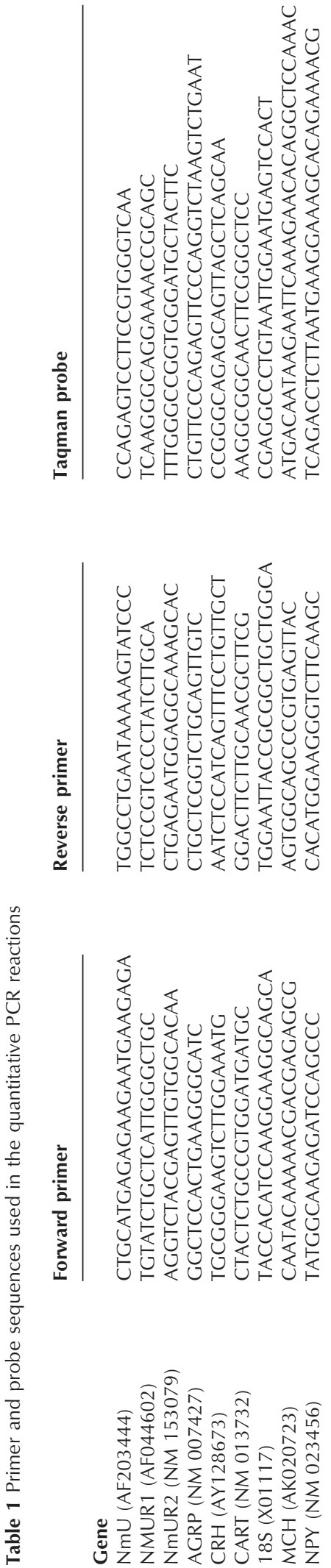
resonance (NMR)-based method (EchoMRI; Echo Medical, Houston, TX, USA (Tinsley et al. 2004)) was used to measure body fat and muscle mass.

\section{Liver lipid determination}

Triglyceride, free cholesterol and cholesteryl esters were determined in a 100-200 mg aliquot of liver. The liver lipids were extracted by the method of Folch et al. (1957) and triglyceride, cholesteryl ester and free cholesterol content were determined by high-performance liquid chromatography analysis, as previously described (Burrier et al. 1995).

\section{Plasma measurements}

Plasma insulin and leptin were measured with ELISA kits (Alpco, Windham, NH, USA and Crystal Chem, Chicago, IL, USA), and triglycerides and free fatty acids were measured by enzymatic colorimetric assays (Sigma and Wako Inc., Richmond, VA, USA). Plasma corticosterone was measured by RIA (ICN, Irvine, CA, USA). Serum NmU concentrations from one male $\mathrm{NmU}$ Tg and one male wild-type littermate were determined with an $\mathrm{NmU}$ dot blot kit according to manufacturer's protocol (Phoenix Pharmaceuticals, Belmont, CA, USA) with the exception that mouse $\mathrm{NmU}$ was used as a standard in place of rat $\mathrm{NmU}$.

\section{Glucose tolerance tests}

Tail blood was collected after $24 \mathrm{~h}$ of food deprivation and basal glucose levels were measured by the glucose oxidase method (Glucometer Elite, Bayer, Elkhart, IN, USA). After this measure, glucose $(1 \mathrm{mg} / \mathrm{g}$ body weight) was administered intraperitoneally, and tail blood was collected at 20, 40, 60, and $90 \mathrm{~min}$ post-dose for glucose determination.

\section{Insulin tolerance tests}

Tail blood was collected after $24 \mathrm{~h}$ of food deprivation and basal glucose levels were measured using a glucose oxidase method (Glucometer Elite). After this measure, insulin $(0.75 \mathrm{mU} / \mathrm{g}$ body weight $)$ was administered intraperitoneally, and tail blood was collected at 20, 40,60, 90, and $120 \mathrm{~min}$ post-dose for glucose determination.

\section{Indirect calorimetry}

Oxygen consumption $\left(V_{\mathrm{O} 2}\right)$ and carbon dioxide production $\left(V_{\mathrm{CO} 2}\right)$ were measured in mice every $30 \mathrm{~min}$ (settle time: $155 \mathrm{~s}$; measure time: $45 \mathrm{~s}$ ) for $23 \mathrm{~h}$ with the use of an indirect calorimeter (Oxymax, Columbus Instruments, Columbus, OH, USA). Measurements were taken in an airtight container $(2.5 \mathrm{l})$ with an air flow rate of $0.5 \mathrm{l} / \mathrm{min}$; 27-28-week-old wild-type $(n=8)$ and $\operatorname{Tg}(n=8)$ mice were acclimated to the chambers for 4 days prior to measurement, and were monitored in the fed state, during 24-h food deprivation, and during $24 \mathrm{~h}$ of refeeding. Respiratory quotient (RQ) was calculated as the molar ratio of $V_{\mathrm{CO} 2}: V_{\mathrm{O} 2}$. The $V_{\mathrm{O} 2}$ and $\mathrm{RQ}$ values from four consecutive readings, encompassing a 2 -h period, were averaged for analysis.

\section{Behavioral studies}

Two cohorts of $\mathrm{NmU} \mathrm{Tg}$ mice $(n=11$ and 14) and wild-type littermates $(n=14$ and 15) were maintained on chow and tested in a behavioral battery including the following: the primary observational screen from the SHIRPA protocol (Rogers et al. 1999), locomotor activity (LMA; Coulbourn Tru-Scan, 60 min), elevated plus maze (transparent closed arms, $5 \mathrm{~min}$ ), accelerating rotarod (Accuscan SmartRod, eight trials, acceleration rate: 20 r.p.m./60 s), spatial Y-maze (Dellu et al. 2000), motor coordination battery (Lalonde et al. 1994, 1997, Klein et al. 1996, Carter et al. 1999, Contet et al. 2001), hotplate (Schreiber et al. 1996), tail suspension (Steru et al. 1985), forced swim (Redrobe \& Bourin 1998), warm water tail flick (Janssen 1963), auditory startle threshold (Varty et al. 2001), prepulse inhibition of auditory startle (Varty et al. 2001), passive avoidance (one-trial step-through, 2 s $0.6 \mathrm{~mA}, 24-\mathrm{h}$ retention, $300 \mathrm{~s}$ maximum) and pentylenetetrazole-induced seizure threshold (Nutt et al. 1986). The group housed mice began testing when they were 12-24 weeks and ended when they were 20-31 weeks of age.

\section{GI transit studies}

Chow-fed mice were starved for $24 \mathrm{~h}$, after which time a bolus dose $(0.4 \mathrm{ml})$ of a charcoal mixture (1\% methylcellulose: $5 \%$ acacia: $10 \%$ charcoal) was orally administered. After $20 \mathrm{~min}$, the animals were killed by $\mathrm{CO}_{2}$ asphyxiation, the GI tract from the stomach to cecum was removed, and the distance traveled by the charcoal mixture was measured and expressed as percentage of the total intestinal length.

\section{Statistical analysis}

Values are reported as means \pm S.E.M. except where indicated. Statistical significance of body weight, daily food intake, plasma measures and neuropeptide expression between genotypes was determined by Student's $t$-test. Differences in $V_{\mathrm{O} 2}$ and $\mathrm{RQ}$ during the dark and light phases of the fed, fasted and refed states were analyzed by repeated measures analysis of variance, followed by Fisher's PLSD where appropriate. A $P$ value of $<0.05$ was considered significant. 
Table 2 Expression of neuromedin $U(\mathrm{NmU})$ and the neuromedin $U$ receptors (NmUR1 and NmUR2) in tissues from 8-week-old wild-type (wt) mice and $\mathrm{NmU}$-overexpressing mice ( $\mathrm{NmU} \mathrm{Tg}$ ). Values are expressed as fg/reaction for each mouse ( $n=2$ per genotype)

\begin{tabular}{|c|c|c|c|c|c|c|}
\hline & \multicolumn{2}{|l|}{$\mathrm{NmU}$} & \multicolumn{2}{|l|}{ NmUR1 } & \multicolumn{2}{|l|}{ NmUR2 } \\
\hline & WT & NmU Tg & WT & NmU Tg & WT & NmU Tg \\
\hline \multicolumn{7}{|l|}{ Tissue/genotype } \\
\hline Spleen & $0.06,0.06$ & 16950,6750 & $0 \cdot 65,0 \cdot 82$ & $2 \cdot 02,0.68$ & $0 \cdot 34,1 \cdot 36$ & $2 \cdot 21,0 \cdot 47$ \\
\hline Stomach & $67 \cdot 30,17 \cdot 85$ & 21400,12050 & $0 \cdot 72,0.64$ & $0 \cdot 66,0.32$ & $0 \cdot 28,0 \cdot 10$ & $0 \cdot 13,0 \cdot 10$ \\
\hline Intestine & $3 \cdot 23,3 \cdot 23$ & 11210,6510 & $11 \cdot 85,4 \cdot 84$ & $5 \cdot 24,3 \cdot 11$ & $7 \cdot 85,4 \cdot 15$ & $3 \cdot 73,2 \cdot 50$ \\
\hline Hypothalamus & $0 \cdot 22,0 \cdot 10$ & 448,276 & $0 \cdot 41,0 \cdot 69$ & $0.59,0.68$ & $4 \cdot 28,4 \cdot 28$ & $3 \cdot 52,2 \cdot 41$ \\
\hline Hippocampus & $0 \cdot 04,0.04$ & 292, 589 & $0 \cdot 17,0 \cdot 35$ & $0 \cdot 72,0 \cdot 29$ & $0 \cdot 51,0 \cdot 47$ & $0 \cdot 85,0 \cdot 38$ \\
\hline Brainstem & $1 \cdot 05,0 \cdot 15$ & 1222,993 & $2 \cdot 05,4 \cdot 70$ & $3 \cdot 00,4 \cdot 40$ & $8 \cdot 09,6 \cdot 82$ & $3 \cdot 90,5 \cdot 10$ \\
\hline Spinal cord & $1 \cdot 01,0.53$ & 564,565 & $0 \cdot 75,1 \cdot 04$ & $0.47,0.51$ & $14 \cdot 3,9 \cdot 21$ & $5 \cdot 11,5 \cdot 66$ \\
\hline
\end{tabular}

\section{Results}

\section{Generation of $\mathrm{Tg}$ mice}

Mice overexpressing murine $\mathrm{NmU}$ were generated in the C57BL/6 DBA2/J background (B6D2) using the CMV$\mathrm{NmU}$ transgene. In this transgene, $\mathrm{NmU}$ is expressed from a human CMV enhancer-chicken $\beta$-actin promoter cassette which directs expression to virtually all tissues (Okabe et al. 1997). A total of two Tg founders were generated as determined by PCR genotyping. The line that displayed the highest level of transgene expression was used in all studies reported. The mice developed and reproduced normally and did not show any visible pathologic abnormalities. Overall, there were no robust or reproducible differences between $\mathrm{NmU} \mathrm{Tg}$ mice and wild-type mice in any of the behavioral measures including LMA (data not shown).

\section{Expression analysis}

As shown in Table 2, the NmU transgene was expressed at high levels in all tissues examined, including throughout the CNS. Despite this high level of $\mathrm{NmU}$ transgene expression, there was no apparent up- or downregulation of $\mathrm{NmU}$ receptor mRNA (Table 2). Localization of the $\mathrm{NmU}$ transgene expression in the brain indicated that overexpression was ubiquitous but particularly apparent in the paraventricular, supraoptic, suprachiasmatic and arcuate nuclei of the hypothalamus, the piriform cortex and the CA3 field of the hippocampus (Fig. 1). This pattern of brain $\mathrm{NmU}$ overexpression was similar in all three Tg mice studied. Because transcriptional regulation of the $\mathrm{NmU}$ transgene was under the control of the human CMV enhancer/chicken $\beta$-actin promoter, and not the endogenous promoter, it is unlikely that nutritional state or other physiologic alterations affected $\mathrm{NmU}$ transgene expression to any appreciable extent.
In order to detect active peptide, spleen cells (total spleen) from a $\mathrm{Tg}$ mouse and a non- $\mathrm{Tg}$ littermate were cultured in serum-free RPMI (without phenol red) for 5 days, and the conditioned medium was subsequently assayed for $\mathrm{NmU}$ activity, using $\mathrm{NmU}-\mathrm{R} 2$-expressing HEK293 cells (Shan et al. 2000). A calcium flux was detected in response to the addition of medium from the Tg spleen cells (Fig. 2) while a much smaller response was detected using medium from wild-type spleen cells. These data suggest that bioactive $\mathrm{NmU}$ is produced from the $\mathrm{Tg}$ proNmU gene. The serum NmU concentration determined with a dot blot kit was between 50 and $100 \mathrm{nM}$ in an NmU Tg mouse and below the level of detection in a wild-type littermate, indicating that the bioactive $\mathrm{NmU}$ is secreted into the blood.

The effect of the $\mathrm{NmU}$ transgene on food intake and body composition

The body weight of 24-30-week-old chow-fed NmU Tg mice was significantly less $(\sim 14 \%)$ than wild-type mice (Table 3). NmU Tg mice had significantly smaller epididymal, inguinal, retroperitoneal and mesenteric adipose depots (Fig. 3A), and 33\% less total dissectible fat $(10 \cdot 9 \pm 0.8$ vs $8 \cdot 4 \pm 0 \cdot 6 \%$ of body weight for wild-type and $\mathrm{NmU}$ Tg mice respectively; $P<0 \cdot 05)$. Consistent with these findings, $\mathrm{NmU} \mathrm{Tg}$ mice had significantly lower plasma leptin levels (Table 3). There was no significant difference in nasoanal length or rectal temperature between genotypes (data not shown). The liver weight of $\mathrm{NmU}$ Tg mice was significantly less than wild-type mice, even when expressed as a function of body weight. This was accompanied by significantly less triglyceride (Table 4). There were no significant differences in plasma triglycerides, free fatty acids or corticosterone between genotypes (Table 3). In a separate cohort of 28-week-old, chow-fed mice, NMR analysis confirmed the lower 
adiposity of $\mathrm{NmU} \mathrm{Tg}$ mice (fat mass of $12 \cdot 0 \pm 1.5 \mathrm{~g}$ vs $6.9 \pm 1.4 \mathrm{~g}(P<0.05)$ and lean mass of $21.4 \pm 0.6 \mathrm{~g}$ vs $21 \cdot 3 \pm 0.9$ (n.s.) for wild-type and $\mathrm{Tg}$ mice respectively).

$\mathrm{NmU} \mathrm{Tg}$ mice were hypophagic, with average daily intake (calculated from 24 consecutive days of food intake measures) 20\% less per day than wild-type animals (Fig. 4A). This difference remained when intake was expressed as a function of metabolic mass $\left(\mathrm{kcal} /(\mathrm{g} \text { body weight })^{0.75}\right)$, with $\mathrm{NmU} \mathrm{Tg}$ mice eating significantly less than wildtype mice (Fig. 4B). The hypophagic phenotype of $\mathrm{NmU}$ $\mathrm{Tg}$ mice was accompanied by significant differences in anorexigenic and orexigenic hypothalamic neuropeptides

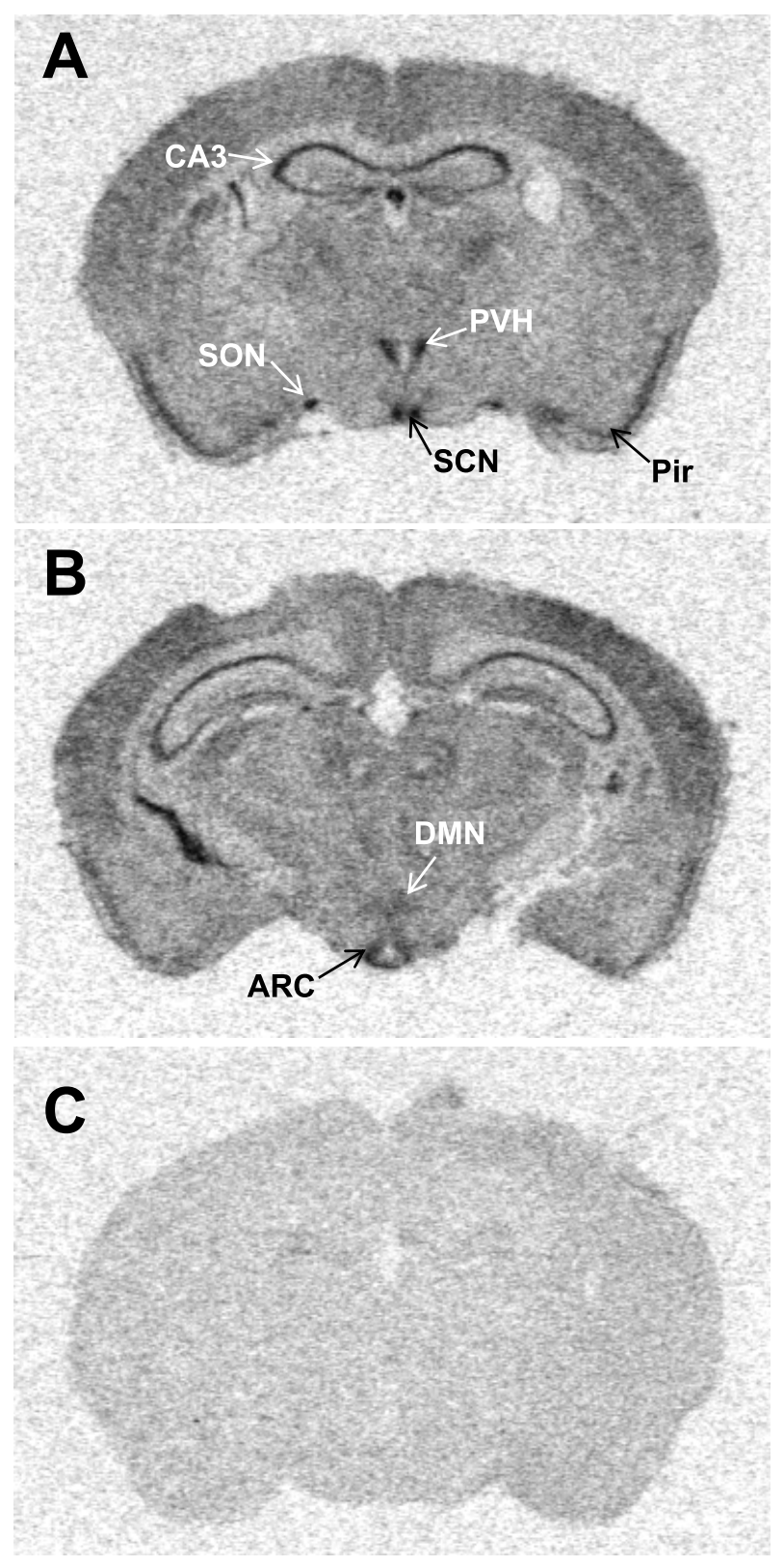

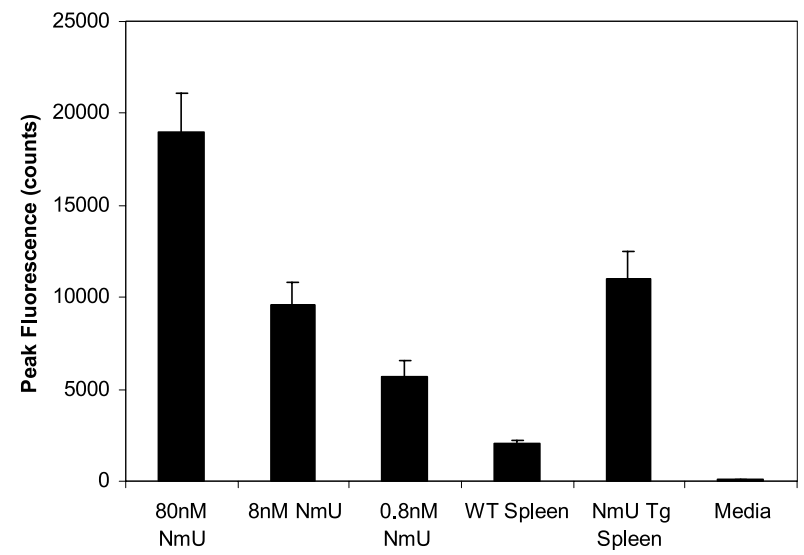

Figure $2 \mathrm{NmU}$ activity is detected in culture supernatant from $\mathrm{Tg}$ spleen cells. Spleen cells from an 8-week-old wild-type or $\mathrm{NmU} \mathrm{Tg}$ mouse were cultured in serum-free medium for 5 days and then assayed for the ability to flux calcium in HEK293 cells stably expressing human NmU-R2. Human NmU-25 was used at the indicated concentrations as a positive control while unconditioned medium was used as a negative control. Data points are the mean of at least triplicate determinations with standard deviation shown.

(Table 5). Specifically, NmU Tg mice had higher levels of NPY, POMC and MCH expression. No differences in CART, AgRP and corticotropin-releasing hormone $(\mathrm{CRH})$ were observed between genotypes. Additionally, the GI transit time was measured in the $\mathrm{NmU} \mathrm{Tg}$ and wild-type mice, and no significant effect was found (charcoal distance was $57 \cdot 5 \pm 1 \cdot 2$ vs $51 \cdot 6 \pm 3.3 \%$ of intestinal length for $\mathrm{NmU} \operatorname{Tg}(n=14)$ and wild-type $(n=13)$ mice respectively; n.s.).

\section{The effect of the $N m U$ transgene on glucose homeostasis}

There was no significant effect of the $\mathrm{NmU}$ transgene on fasting glucose levels in chow-fed animals (Table 3). Insulin levels, however, were significantly lower in $\mathrm{Tg}$ mice (Table 3). Glucose tolerance, judged by an intraperitoneal glucose tolerance test (ipGTT), was similar between wild-type and $\mathrm{Tg}$ mice (data not shown); however, the $\mathrm{Tg}$ mice had improved insulin sensitivity (intraperitoneal insulin tolerance test (ipITT); Fig. 5).

Figure 1 Localization of $\mathrm{NmU}$ mRNA in mouse brain by in situ hybridization. Autoradiograms showing the overexpression of $\mathrm{NmU}$ in coronal sections of a Tg mouse at the level of the hypothalamic paraventricular (A) and arcuate (B) nuclei (bregma -0.82 and $-1 \cdot 82$ for $A$ and $B$ respectively), and a wild-type mouse at the level of the hypothalamic paraventricular nuclei (C). While the expression appears to be ubiquitous relative to the wild-type brain, the overexpression is particularly apparent in the paraventricular $(\mathrm{PVH})$, suprachiasmatic $(\mathrm{SCN})$, supraoptic $(\mathrm{SON})$, dorsomedial (DMN) and arcuate (ARC) nuclei of the hypothalamus. CA3: field CA3 of the hippocampus; Pir: piriform cortex. 
Table 3 Body weight, plasma leptin, insulin, glucose,

corticosterone, triglycerides and free fatty acids of 24-30-week-old wild-type and $\mathrm{NmU}$ Tg mice maintained on a chow diet $(n=17-20$ animals per group)

\begin{tabular}{|c|c|c|}
\hline & Wild-type & $\mathrm{NmU} \mathrm{Tg}$ \\
\hline \multicolumn{3}{|l|}{ Measure } \\
\hline Body weight (g) & $39 \cdot 8 \pm 1 \cdot 3$ & $34 \cdot 4 \pm 1 \cdot 1^{*}$ \\
\hline Leptin (ng/ml) & $19 \cdot 4 \pm 3 \cdot 27$ & $5 \cdot 29 \pm 1 \cdot 28$ * \\
\hline Insulin (ng/ml) & $4.59 \pm 0.94$ & $1.96 \pm 0.69 *$ \\
\hline Fasting glucose (mM) & $4 \cdot 6 \pm 0 \cdot 2$ & $4 \cdot 4 \pm 0 \cdot 2$ \\
\hline Corticosterone $(\mathrm{ng} / \mathrm{ml})$ & $53 \cdot 1 \pm 8 \cdot 6$ & $76 \cdot 9 \pm 12 \cdot 4$ \\
\hline Triglycerides (mM) & $1 \cdot 99 \pm 0 \cdot 2$ & $1 \cdot 96 \pm 0 \cdot 2$ \\
\hline Free fatty acids (mM) & $0.559 \pm 0.035$ & $0 \cdot 552 \pm 0.044$ \\
\hline
\end{tabular}

*, significantly different from wild-type animals.

\section{Energy expenditure}

There was a significant effect of genotype on body weight in the cohort of mice used in these studies $(33 \cdot 4 \pm 1 \cdot 1 \mathrm{vs}$ $39.6 \pm 1.7 \mathrm{~g}$ for $\mathrm{NmU} \mathrm{Tg}$ and wild-type respectively $(P<0 \cdot 01))$. There was no significant effect of genotype on $V_{\mathrm{O} 2}\left(\mathrm{ml} / \mathrm{min}\right.$ per $\left.\mathrm{kg}^{0 \cdot 75}\right)$ during ad libitum feeding, a $24-\mathrm{h}$ fast, or the subsequent $24 \mathrm{~h}$ of refeeding (Fig. 6A). The $\mathrm{RQ}$ of $\mathrm{Tg}$ mice was significantly higher during the dark phase $\left(F_{1.14}=2.67 ; P<0.05\right)$ and the light phase $\left(\mathrm{F}_{1,14}=12.55 ; P<0.005\right)$ of a $24-\mathrm{h}$ fast, and in the dark phase of the refeeding period $\left(\mathrm{F}_{1,14}=10 \cdot 3 ; P<0 \cdot 01\right)$ (Fig. $6 \mathrm{~B})$, indicating that the transition toward fat oxidation with fasting was attenuated in the $\mathrm{Tg}$ mice. The higher RQ with refeeding was not due to alterations in the rate of eating when food was presented after a 24-h fast (data not shown).

\section{The effect of the $N m U$ transgene on diet-induced obesity}

At $15-18$ weeks of age, wild-type $(n=8)$ and $\mathrm{NmU} \mathrm{Tg}$ mice $(n=8)$ were placed on a high-fat diet. Initial body weights of $\mathrm{NmU} \mathrm{Tg}$ mice in this cohort were significantly lower than wild-type mice $(29 \cdot 7 \pm 1 \cdot 3$ vs $36 \cdot 3 \pm 0.8 \mathrm{~g}$; $P<0 \cdot 005)$, similar to the findings in mice reported above. Food intake and body weight gain were monitored daily for 20 days. The $\mathrm{NmU} \mathrm{Tg}$ mice ate significantly less than wild-type mice (cumulative intake of $321 \pm 11$ vs $390 \pm 9 \mathrm{kcal} /$ mouse for $\mathrm{NmU} \mathrm{Tg}$ and wild-type mice respectively; $P<0 \cdot 05)$; however, there was no statistical difference when daily intake was expressed as a function of metabolic mass $(1.21 \pm 0.03 \mathrm{vs} 1.14 \pm 0.03 \mathrm{kcal} /(\mathrm{g}$ body weight $)^{0.75}$ for wild-type and $\mathrm{NmU} \mathrm{Tg}$ mice respectively). Furthermore, there was no significant difference in feed efficiency during this 20 -day period $(11 \cdot 8 \pm 0.6$ vs. $10 \cdot 3 \pm 2 \cdot 0 \mathrm{kcal} / \mathrm{g}$ body-weight gain for wild-type and $\mathrm{NmU} \mathrm{Tg}$, mice respectively).

After 11 weeks on the high-fat diet, the $\mathrm{NmU}$ Tg mice weighed significantly less than wild-type mice; however, there was no significant effect of the transgene on percent
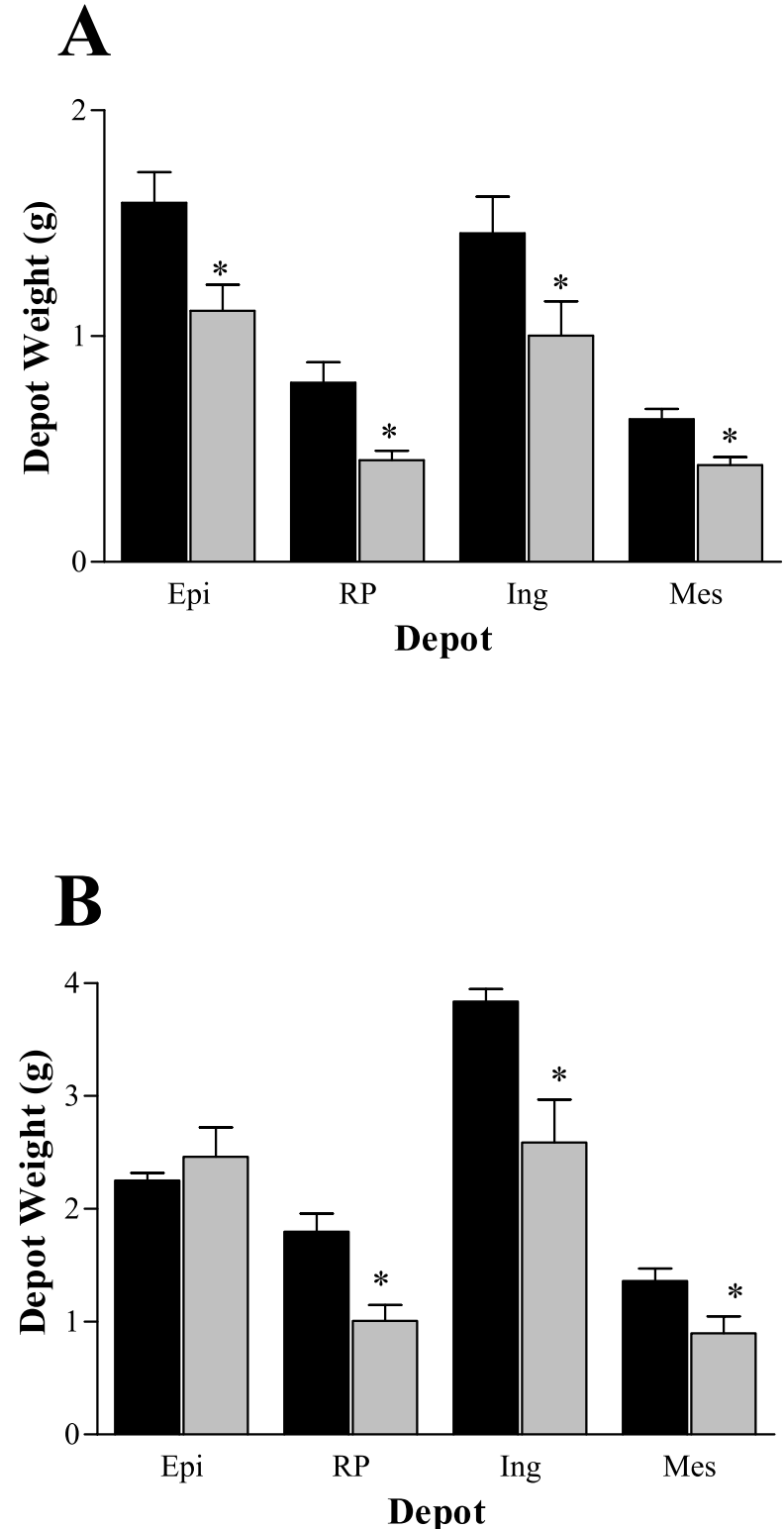

Figure 3 Epididymal (Epi), retroperitoneal (RP), inguinal (Ing) and mesenteric (Mes) adipose depot weights of (A) 24-32-week-old wild-type and $\mathrm{NmU}$ Tg mice that were maintained on chow ( $n=17-20$ per group) or (B) 20-24-week-old wild-type and $\mathrm{NmU}$ Tg mice maintained on chow and then switched to a high-fat diet for 11 weeks ( $n=7-8$ per group). Black bars: wild-type; gray bars: $\mathrm{NmU} \mathrm{Tg.} \mathrm{*}$ Significantly different from wild-type animals $(P<0 \cdot 05)$

body-weight gain over this time (Table 6). NmU Tg mice had significantly smaller retroperitoneal, mesenteric and inguinal fat pad weights (Fig. 3B), with a trend toward less total dissectible fat content $(18 \cdot 6 \pm 0 \cdot 4$ vs $16 \cdot 7 \pm 1 \cdot 3 \%$ of body weight for wild-type and $\mathrm{NmU} \mathrm{Tg}$ mice respectively; $P=0.089$ ). Consistent with the lower fat mass, $\mathrm{NmU} \mathrm{Tg}$ mice had significantly lower plasma leptin levels (Table 6). 
Table 4 Liver weight and lipids of 24-30-week-old wild-type and $\mathrm{NmU} \mathrm{Tg}$ mice maintained on a chow diet $(n=17-20$ animals per group)

\begin{tabular}{|c|c|c|}
\hline & Wild-type & NmU Tg \\
\hline \multicolumn{3}{|l|}{ Measure } \\
\hline Liver weight (g) & $1 \cdot 94 \pm 0 \cdot 13$ & $1 \cdot 43 \pm 0.05^{*}$ \\
\hline Liver (\% body weight) & $4 \cdot 82 \pm 0 \cdot 2$ & $4 \cdot 17 \pm 0 \cdot 10^{*}$ \\
\hline \multicolumn{3}{|l|}{ Liver lipids (mg/g liver) } \\
\hline Triglyceride & $77 \cdot 5 \pm 10 \cdot 9$ & $50 \cdot 7 \pm 5 \cdot 8^{*}$ \\
\hline Cholesteryl ester & $3 \cdot 70 \pm 0 \cdot 13$ & $3 \cdot 59 \pm 0 \cdot 24$ \\
\hline Free cholesterol & $0 \cdot 74 \pm 0 \cdot 07$ & $0 \cdot 85 \pm 0 \cdot 11$ \\
\hline
\end{tabular}

*, significantly different from wild-type animals.

The liver weights of $\mathrm{NmU} \mathrm{Tg}$ mice were significantly less than wild-type mice when expressed as absolute weight or as percentage of body weight (Table 7). This smaller liver weight in $\mathrm{NmU} \mathrm{Tg}$ mice was accompanied by significantly less triglyceride and cholesteryl ester (Table 7).

\section{Glucose tolerance after high-fat feeding}

After 8 weeks on the high-fat diet, plasma insulin levels in $\mathrm{NmU} \mathrm{Tg}$ mice were approximately $30 \%$ of those in wild-type mice (Table 6), and there was a trend toward a significant effect of the transgene on fasting glucose concentrations $(114.3 \pm 7 \cdot 0 \mathrm{vs} 98 \cdot 6 \pm 4 \cdot 1 \mathrm{mg} / \mathrm{dl}$ for wildtype and $\mathrm{NmU} \mathrm{Tg}$ mice respectively; $P=0 \cdot 076)$. Consistent with the attenuated hyperinsulinemia, the transgene had a significant effect on glucose tolerance (Fig. 7), indicating that the negative impact of high-fat feeding on glucose homeostasis was partially corrected by the presence of the $\mathrm{NmU}$ transgene.

\section{Discussion}

$\mathrm{NmU}$ has been implicated in the control of food intake and body weight regulation. We show that mice possessing a human CMV enhancer/chicken $\beta$-actin-pro-NmU transgene broadly overexpress murine pro- $\mathrm{NmU}$, and that bioactive peptide can be produced from the transgene. $\mathrm{NmU}$ Tg mice maintained on a chow diet are hypophagic and lean relative to wild-type mice, and display improved insulin sensitivity. There is no significant effect of $\mathrm{NmU}$ overexpression on $V_{\mathrm{O} 2}$ or locomotor activity. Furthermore, when fed a high-fat diet, $\mathrm{NmU} \mathrm{Tg}$ mice remain leaner than wild-type mice, although they are not refractory to an increase in adiposity with high-fat feeding. Despite the weight gain, high-fat-fed $\mathrm{NmU} \mathrm{Tg} \mathrm{mice}$ display improved glucose tolerance. Collectively, these findings support the hypothesized role of $\mathrm{NmU}$ as an anorectic peptide involved in regulation of energy homeostasis.
A

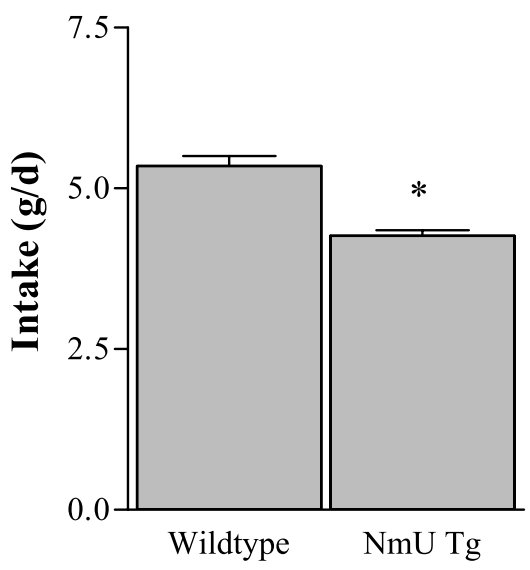

B

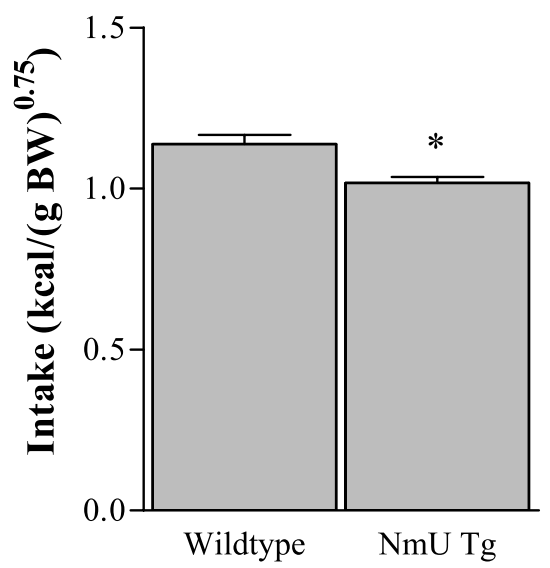

Figure 4 Effect of the $\mathrm{NmU}$ transgene on average daily food intake in 24-32-week-old chow- fed mice. Food intake, expressed as grams per day $(\mathrm{A})$ or as $\mathrm{kcal} /(\mathrm{g} \text { body weight }(\mathrm{BW}))^{0.75}$ per day (B), is an average over a 24-day period. $n=17-20$ per group. ${ }^{*}$ Significantly different from wild-type controls $(P<0 \cdot 05)$.

Because NmU expression (and presumably synthesis and release) in hypothalamic and hindbrain neurons is regulated by nutritional state (Ivanov et al. 2002), and i.c.v. or intra-PVN administration of $\mathrm{NmU}$ elicits robust anorexigenic effects (Howard et al. 2000, Kojima et al. 2000, Nakazato et al. 2000, Wren et al. 2002), NmU probably exerts its effects on food intake and energy expenditure within the CNS, perhaps through NmU-R2 (Shan et al. 2000). Consistent with this, we show that the transgene is expressed throughout the CNS and that its presence 
Table 5 Expression of neuropeptide mRNAs in the hypothalamus of 30-week-old wild-type $(n=9)$ mice and mice overexpressing $\mathrm{NmU}(\mathrm{NmU} \mathrm{Tg} ; n=8)$ maintained on a chow diet. Units are $\mathrm{fg} /$ reaction except for $18 \mathrm{~S}$, which is expressed as $\mathrm{pg} /$ reaction

\begin{tabular}{|c|c|c|}
\hline \multirow[b]{2}{*}{ Gene } & Wild-type & $\mathrm{NmU} \mathrm{Tg}$ \\
\hline & & \\
\hline $18 S$ & $2748 \pm 116$ & $2732 \pm 88$ \\
\hline $\mathrm{NmU}$ & $0.063 \pm 0.008$ & $369 \pm 21^{*}$ \\
\hline NPY & $3050 \pm 260$ & $4570 \pm 670^{*}$ \\
\hline POMC & $7960 \pm 530$ & $13550 \pm 1900^{*}$ \\
\hline CART & $390 \pm 50$ & $380 \pm 30$ \\
\hline $\mathrm{MCH}$ & $1450 \pm 100$ & $2070 \pm 180^{*}$ \\
\hline AgRP & $138 \pm 14$ & $130 \pm 19$ \\
\hline $\mathrm{CRH}$ & $0 \cdot 84 \pm 0 \cdot 1$ & $0 \cdot 85 \pm 0 \cdot 15$ \\
\hline
\end{tabular}

*, significantly different from wild-type animals.

confers effects on feeding and body weight that are consistent with the actions produced by exogenous central administration of $\mathrm{NmU}$.

The overexpression of $\mathrm{NmU}$ significantly altered the expression of several hypothalamic neuropeptides implicated in the regulation of food intake and energy expenditure. Chow-fed NmU Tg mice had levels of NPY, POMC and MCH mRNA that were higher than those of wild-type mice. Higher expression of POMC may result in an increased production and release of $\alpha-\mathrm{MSH}$, a potent anorexigenic peptide acting as an agonist at melanocortin 4 receptors, thus providing a possible mechanism driving the hypophagia in response to $\mathrm{NmU}$ overexpression. Because NPY and MCH are orexigenic, the higher expression level of these may be compensatory to the lower body weight, lower circulating leptin, or hypophagia. The hypophagia in Tg mice that occurs despite elevated NPY and $\mathrm{MCH}$ expression suggests that $\mathrm{NmU}$ may be involved

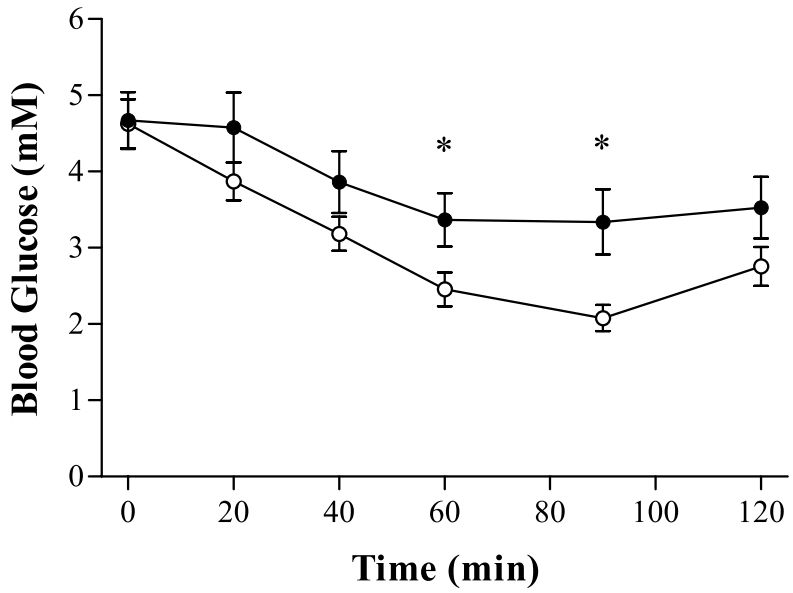

Figure 5 Effect of the $\mathrm{NmU}$ transgene on insulin sensitivity (determined by ipITT) in 24-32-week-old, chow-fed mice. Filled circles: wild-type; open circles: $\mathrm{NmU}$ Tg. $n=9$ per group.

${ }^{*}$ Significantly different from wild-type animals $(P<0 \cdot 05)$. in the downstream effects of these two neuropeptides. Further work examining the responsiveness of these animals to exogenous administration of orexigenic and anorexigenic peptides, as well as deprivation-induced changes in expression of these neuropeptides, may provide more insight.

The lean phenotype of the NmU-overexpressing mice appears to be predominantly due to hypophagia, as it occurs in the absence of behavioral changes that might otherwise contribute to reduced body weight (e.g. increased activity) or an increased oxygen consumption indicating hypermetabolism. The failure to detect hyperactivity or hyperthermia in $\mathrm{NmU} \mathrm{Tg}$ mice was surprising in light of the reported increase in locomotor activity and rectal temperature after i.c.v. $\mathrm{NmU}$ administration (Howard et al. 2000, Nakazato et al. 2000, Hanada et al. 2001). One possible reason for this discrepancy is that an acute increase in $\mathrm{NmU}$ signaling, as occurs with i.c.v. administration, promotes a response that is different from that seen with chronic NmU signaling. Because the relative expression of the transgene within the hypothalamus is variable between nuclei, it is also possible that $\mathrm{NmU}$ is not elevated in all the relevant neurons required to elicit an effect on locomotor activity and body temperature. Lastly, the expression level or localization of central $\mathrm{NmU}$ receptors may be altered by the chronic $\mathrm{NmU}$ signaling in Tg mice. Our data do not support the latter possibility as evidenced by no gross difference in NmU-R1 and -R2 mRNA in all tissues studied; however, subtle changes in expression or differences in neural distribution of receptors may be present.

Prior reports have shown that central administration of $\mathrm{NmU}$ increases hypothalamic CRH expression, and that central or peripheral $\mathrm{NmU}$ administration increases plasma adrenocorticotropic hormone $(\mathrm{ACTH})$ and corticosterone (Malendowicz et al. 1994, Wren et al. 2002). Furthermore, the hyperactivity associated with central NmU administration is abolished in CRH knockout mice or after treatment with a CRH-R1 antagonist (Hanada et al. 2001). Interestingly, we found no significant difference in hypothalamic CRH expression or plasma corticosterone levels between chow-fed, wild-type and NmU Tg mice, despite the elevated $\mathrm{NmU}$ expression in the PVN of Tg mice. These findings indicate that the hypophagia observed in the $\mathrm{NmU}$ Tg mice is unlikely to be a result of a heightened $\mathrm{CRH}$ tone; however, measures of $\mathrm{CRH}$ protein and pharmacologic responses to $\mathrm{CRH}$ receptor antagonists are required to fully evaluate this.

Evaluation of energy expenditure by indirect calorimetry showed no effect of genotype on $V_{\mathrm{O} 2}$, observations that are not consistent with those demonstrating a 20\% increase in oxygen consumption with i.c.v. NmU administration (Hanada et al. 2003). It is possible that the reported increase in $V_{\mathrm{O} 2}$ after i.c.v. $\mathrm{NmU}$ administration is due to an increase in locomotor activity and grooming behavior, and not to increased thermogenesis 


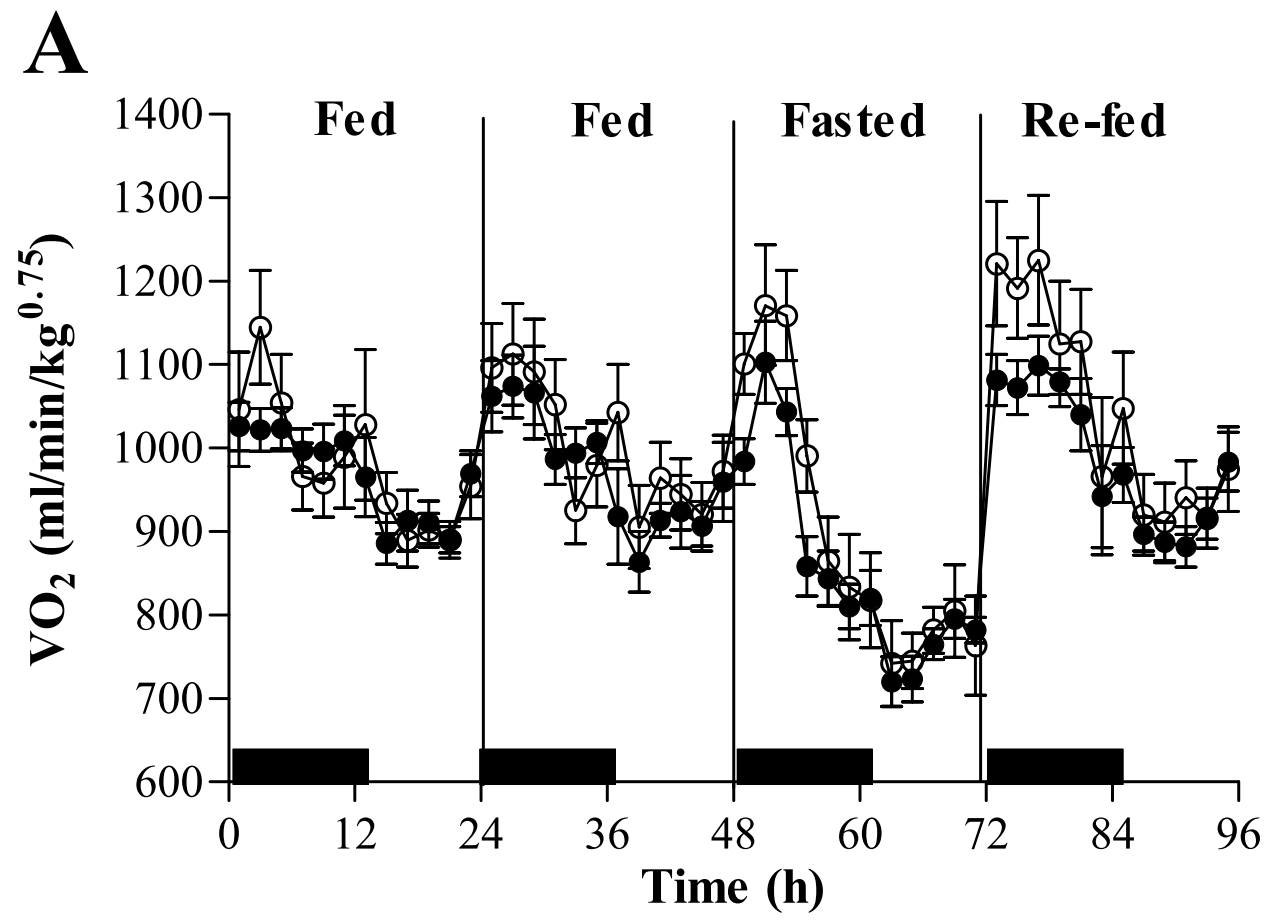

B

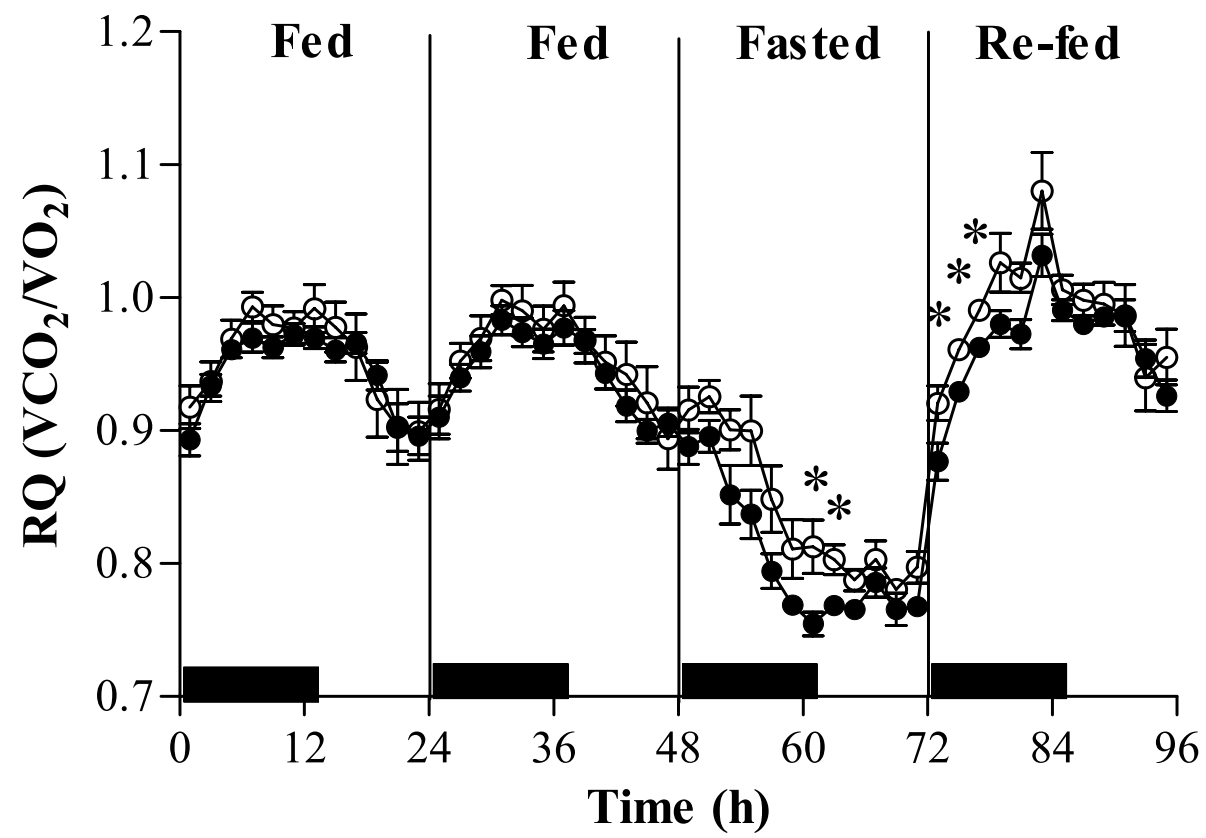

Figure 6 Effect of the $\mathrm{NmU}$ transgene on (A) $V_{\mathrm{O} 2}$ and (B) RQ during the fed state, a 24-h fast and $24 \mathrm{~h}$ of refeeding in 27-28-week-old mice. Filled circles: wild-type; open circles: $\mathrm{NmU}$ Tg. $n=8$ per group.

*Significantly different from wild-type animals $(P<0 \cdot 05)$. 
Table 6 Terminal body weight and weight gain, plasma leptin insulin, triglycerides and free fatty acids of 27-30-week-old wild-type $(n=8)$ and $\mathrm{NmU} \mathrm{Tg}(n=7)$ mice after 11 weeks of high-fat feeding

\begin{tabular}{|c|c|c|}
\hline \multirow[b]{2}{*}{ Measure } & \multirow[t]{2}{*}{ Wild-type } & \multirow[t]{2}{*}{$\mathrm{NmU} \mathrm{Tg}$} \\
\hline & & \\
\hline Final body weight (g) & $49 \cdot 7 \pm 0 \cdot 9$ & $40 \cdot 7 \pm 2 \cdot 7^{*}$ \\
\hline Body weight gain (g) & $13 \cdot 5 \pm 0 \cdot 7$ & $10 \cdot 9 \pm 1 \cdot 4$ \\
\hline Body weight gain (\%) & $37 \cdot 9 \pm 2 \cdot 5$ & $36 \cdot 2 \pm 3 \cdot 6$ \\
\hline Leptin $(\mathrm{ng} / \mathrm{ml})$ & $71 \cdot 1 \pm 3 \cdot 1$ & $47 \cdot 5 \pm 10 \cdot 7^{*}$ \\
\hline Insulin (ng/ml) & $57 \cdot 1 \pm 12 \cdot 6$ & $15 \cdot 7 \pm 9 \cdot 3^{*}$ \\
\hline Triglycerides (mM) & $0 \cdot 89 \pm 0 \cdot 1$ & $0 \cdot 89 \pm 0 \cdot 2$ \\
\hline Free fatty acids (mM) & $1 \cdot 17 \pm 0 \cdot 09$ & $1 \cdot 31 \pm 0 \cdot 10$ \\
\hline
\end{tabular}

*, significantly different from wild-type animals.

(Howard et al. 2000, Ivanov et al. 2002, Wren et al. 2002, Hanada et al. 2003). The lack of behavioral differences between wild-type and $\mathrm{NmU} \mathrm{Tg} \mathrm{mice} \mathrm{is} \mathrm{consistent} \mathrm{with}$ this. Interestingly, depriving the mice of food for $24 \mathrm{~h}$ revealed a modest but significantly higher RQ that was

Table 7 Liver weight and lipids of 27-30-week-old wild-type and $\mathrm{NmU}$ Tg mice after 11 weeks of high-fat feeding

\begin{tabular}{|c|c|c|}
\hline \multirow[b]{2}{*}{ Measure } & Wild-type & NmU Tg \\
\hline & & \\
\hline Liver weight (g) & $2 \cdot 24 \pm 0 \cdot 19$ & $1 \cdot 28 \pm 0 \cdot 11^{*}$ \\
\hline Liver (\%BW) & $4 \cdot 49 \pm 0 \cdot 38$ & $3 \cdot 14 \pm 0 \cdot 13^{*}$ \\
\hline
\end{tabular}

Liver lipids (mg/g liver)

Triglyceride Cholesteryl ester

Free cholesterol

$$
\begin{array}{r}
230 \cdot 2 \pm 21 \cdot 6 \\
6 \cdot 67 \pm 0 \cdot 62 \\
1 \cdot 27 \pm 0.08
\end{array}
$$

$109 \cdot 9 \pm 20 \cdot 2^{*}$

$4 \cdot 64 \pm 0 \cdot 45^{*}$

$1 \cdot 41 \pm 0 \cdot 11$

*, significantly different from wild-type animals.

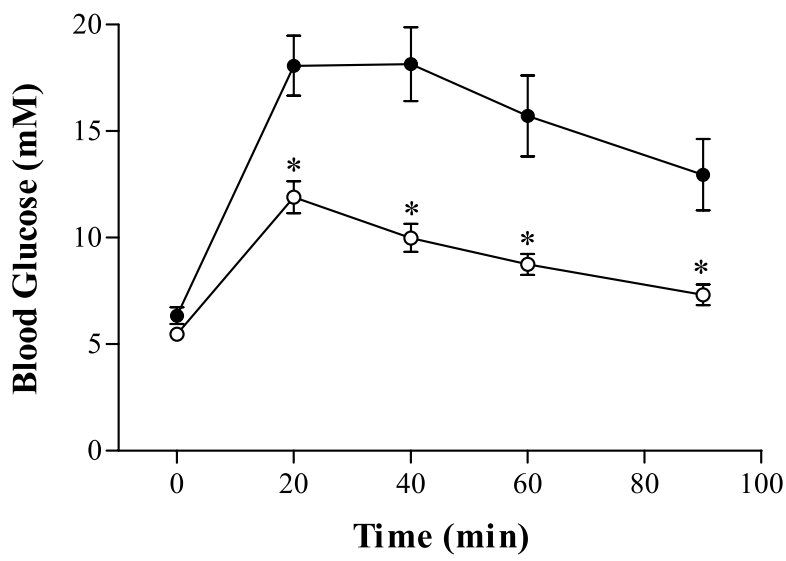

Figure 7 Effect of the $\mathrm{NmU}$ transgene on glucose tolerance after 11 weeks of high-fat feeding in 23-26-week-old mice. Filled circles: wild-type; open circles: $\mathrm{NmU} \mathrm{Tg.} n=8$ per group. AUCs were $14483 \pm 2063$ vs $5908 \pm 615 \mathrm{mg} / \mathrm{dl} . \mathrm{min}$ for $\mathrm{NmU} \mathrm{Tg}$ and wild-type mice respectively $(P<0 \cdot 05)$. *Significantly different from wild-type animals $(P<0 \cdot 05)$. also apparent during the early refeeding phase. Specifically, NmU Tg mice showed an attenuated shift in the transition toward fat oxidation with fasting. Although the mechanism(s) responsible for this shift in substrate oxidation are not known, it is possible that $\mathrm{NmU}$ overexpression provoked subtle changes in circadian oscillations during food deprivation and refeeding. Supporting this hypothesis are studies in rats and mice showing that $\mathrm{NmU}$ is expressed in the SCN (Howard et al. 2000, Nakahara et al. 2004), and that i.c.v. injections of $\mathrm{NmU}$ to rats during the subjective light phase induces a phase shift in the circadian rhythm (Nakahara et al. 2004).

We observed no difference in the intestinal transit of a charcoal-based marker between wild-type and $\mathrm{NmU} \mathrm{Tg}$ mice. Although $\mathrm{NmU}$ stimulates ileal smooth muscle contraction in dogs and humans in vitro (Maggi et al. 1990, Westfall et al. 2002), it failed to stimulate porcine jejunum, guinea pig ileal smooth muscle, and rat small and large intestinal longitudinal smooth muscle in vitro (Minamino et al. 1985a, Brown \& Quito 1988, Benito-Orfila et al. 1991). The absence of a difference between wild-type and $\mathrm{NmU} \mathrm{Tg} \mathrm{mice} \mathrm{in} \mathrm{this} \mathrm{regard} \mathrm{is} \mathrm{therefore} \mathrm{not} \mathrm{entirely}$ surprising, and indicates that changes in intestinal motility are probably not involved in the phenotype observed. Recent work, however, has shown that central administration of $\mathrm{NmU}$ decreases gastric acid secretion and slows gastric emptying in rats (Mondal et al. 2003), potentially affecting meal size and frequency. This contrasts with studies showing that $\mathrm{NmU}$ directly stimulates contraction of rat fundic circular smooth muscle in vitro (Benito-Orfila et al. 1991). Given that there are species differences in smooth muscle contractility in response to $\mathrm{NmU}$ in vitro, studies examining gastric emptying and nutrient absorption are required to fully assess whether changes in GI smooth muscle physiology play a role in the phenotype of these $\mathrm{Tg}$ mice.

The exact mechanism by which the $\mathrm{NmU}$ transgene confers improved glucose homeostasis is not known. There is a strong positive correlation between visceral fat and insulin resistance (Bjorntorp 1991), while reductions in visceral fat mass, either through lipectomy or caloric restriction, have a pronounced effect on hepatic insulin sensitivity in rodents (Barzilai et al. 1999a,b). The reduction in hepatic triglyceride and somatic adipose tissue content associated with the improved glucose homeostasis in $\mathrm{Tg}$ mice is consistent with these observations, suggesting that the lower fat mass of $\mathrm{NmU} \mathrm{Tg} \mathrm{mice} \mathrm{is}$ driving this aspect of the phenotype. It is not known, however, whether this is due to alterations in hepatic insulin sensitivity, peripheral insulin sensitivity, or both. Whether or not the change in glucose homeostasis is due to a fat-mass-independent mechanism remains to be determined.

In summary, we have shown that ubiquitous expression of a transgene encoding murine $\mathrm{NmU}$ in mice produces a lean, hypophagic phenotype with improved glucose 
homeostasis. Based on prior pharmacologic reports, we hypothesize that this phenotype is the result of increased bioactive $\mathrm{NmU}$ peptide and signaling within the CNS. These results suggest that $\mathrm{NmU}$ receptors, particularly NmU-R2, may be a target for the treatment of obesity and eating disorders. Future studies characterizing mice null for the Nmu, Nmur1 and Nmur2 genes will extend these findings, and better define the role of $\mathrm{NmU}$, and the relevant receptors, in feeding behavior and energy homeostasis.

\section{Acknowledgements}

The authors wish to thank Drs Margaret van Heek, Michael Graziano, Maria Wiekowski, John Hunter, Rick Monsma and Marvin Bayne for their support of this project. The authors declare that there is no conflict of interest that would prejudice the impartiality of this scientific work.

\section{References}

Augood SJ, Keast JR \& Emson PC 1988 Distribution and characterisation of neuromedin U-like immunoreactivity in rat brain and intestine and in guinea pig intestine. Regulatory Peptides $\mathbf{2 0}$ 281-292.

Austin C, Lo G, Nandha KA, Meleagros L \& Bloom SR 1995 Cloning and characterization of the cDNA encoding the human neuromedin $\mathrm{U}(\mathrm{NmU})$ precursor: $\mathrm{NmU}$ expression in the human gastrointestinal tract. Journal of Molecular Endocrinology 14 157-169.

Barzilai N, She L, Liu L, Wang J, Hu M, Vuguin P \& Rossetti L $1999 a$ Decreased visceral adiposity accounts for leptin effect on hepatic but not peripheral insulin action. American Journal of Physiology - Endocrinology and Metabolism 277 E291-298.

Barzilai N, She L, Liu BQ, Vuguin P, Cohen P, Wang J \& Rossetti L $1999 b$ Surgical removal of visceral fat reverses hepatic insulin resistance. Diabetes $\mathbf{4 8} 94-98$.

Benito-Orfila MA, Domin J, Nandha KA \& Bloom SR 1991 The motor effect of neuromedin $U$ on rat stomach in vitro. European Journal of Pharmacology 193 329-333.

Bjorntorp P 1991 Metabolic implications of body fat distribution. Diabetes Care 14 1132-1143.

Brighton PJ, Szekeres PG \& Willars GB 2004 Neuromedin U and its receptors: structure, function, and physiological roles. Pharmacological Reviews 56 231-248.

Brown DR \& Quito FL 1988 Neuromedin U octapeptide alters ion transport in porcine jejunum. European Journal of Pharmacology 155 159-162.

Burrier RE, Smith AA, McGregor DG, Hoos LM, Zilli DL \& Davis HR Jr 1995 The effect of acyl CoA: cholesterol acyltransferase inhibition on the uptake, esterification and secretion of cholesterol by the hamster small intestine. Journal of Pharmacology and Experimental Therapeutics 272 156-163.

Carter RJ, Lione LA, Humby T, Mangiarini L, Mahal A, Bates GP, Dunnett SB \& Morton AJ 1999 Characterization of progressive motor deficits in mice transgenic for the human Huntington's disease mutation. Journal of Neuroscience 19 3248-3257.

Contet C, Rawlins JN \& Deacon RM 2001 A comparison of 129S2/SvHsd and C57BL/6 JOlaHsd mice on a test battery assessing sensorimotor, affective and cognitive behaviours: implications for the study of genetically modified mice. Behavioural Brain Research 124 33-46.
Dellu F, Contarino A, Simon H, Koob GF \& Gold LH 2000 Genetic differences in response to novelty and spatial memory using a two-trial recognition task in mice. Neurobiology of Learning and Memory 73 31-48.

Domin J, Ghatei MA, Chohan P \& Bloom SR 1987 Neuromedin U - a study of its distribution in the rat. Peptides 8 779-784.

Domin J, Yiangou YG, Spokes RA, Aitken A, Parmar KB, Chrysanthou BJ \& Bloom SR 1989 The distribution, purification, and pharmacological action of an amphibian neuromedin U. Journal of Biological Chemistry 264 20881-20885.

Folch J, Lees M \& Sloan-Stanley GH 1957 A simple method for isolation and purification of total lipids from animal tissues. Journal of Biological Chemistry 266 497-509.

Fujii R, Hosoya M, Fukusumi S, Kawamata Y, Habata Y, Hinuma S, Onda H, Nishimura O \& Fujino M 2000 Identification of neuromedin $\mathrm{U}$ as the cognate ligand of the orphan $\mathrm{G}$ protein-coupled receptor FM-3. Journal of Biological Chemistry 275 21068-21074.

Funes S, Hedrick J, Yang S, Shan L, Bayne M, Monsma F \& Gustafson E 2002 Cloning and characterization of murine neuromedin U receptors. Peptides 23 1607-1615.

Gardiner SM, Compton AM, Bennett T, Domin J \& Bloom SR 1990 Regional hemodynamic effects of neuromedin $U$ in conscious rats. American Journal of Physiology - Regulatory, Integrative and Comparative Physiology 258 R32-R38.

Gustafson EL, Smith KE, Durkin MM, Walker MW, Gerald C, Weinshank R \& Branchek TA 1997 Distribution of the neuropeptide Y Y2 receptor mRNA in rat central nervous system. Brain Research. Molecular Brain Research 46 223-235.

Hanada R, Nakazato M, Murakami N, Sakihara S, Yoshimatsu H, Toshinai K, Hanada T, Suda T, Kangawa K, Matsukura S et al. 2001 A role for neuromedin U in stress response. Biochemical and Biophysical Research Communications 289 225-228.

Hanada R, Teranishi H, Pearson JT, Kurokawa M, Hosoda H, Fukushima N, Fukue Y, Serino R, Fujihara H, Ueta Y et al. 2004 Neuromedin $U$ has a novel anorexigenic effect independent of the leptin signaling pathway. Nature Medicine 10 1067-1073.

Hanada T, Date Y, Shimbara T, Sakihara S, Murakami N, Hayashi Y, Kanai Y, Suda T, Kangawa K \& Nakazato M 2003 Central actions of neuromedin $\mathrm{U}$ via corticotropin-releasing hormone. Biochemical and Biophysical Research Communications 311 954-958.

Hashimoto T, Masui H, Uchida Y, Sakura N \& Okimura K 1991 Agonistic and antagonistic activities of neuromedin U-8 analogs substituted with glycine or D-amino acid on contractile activity of chicken crop smooth muscle preparations. Chemical and Pharmaceutical Bulletin 39 2319-2322.

Hedrick JA, Morse K, Shan L, Qiao X, Pang L, Wang S, Laz T, Gustafson EL, Bayne M \& Monsma FJ Jr 2000 Identification of a human gastrointestinal tract and immune system receptor for the peptide neuromedin U. Molecular Pharmacology 58 870-875.

Hogan B, Constantini F \& Lacy L 1986 Manipulating the Mouse Embryo. Cold Spring Harbor, NY: Cold Spring Harbor Laboratory Press.

Honzawa M, Sudoh T, Minamino N, Tohyama M \& Matsuo H 1987 Topographic localization of neuromedin U-like structures in the rat brain: an immunohistochemical study. Neuroscience 23 1103-1122.

Honzawa M, Sudoh T, Minamino N, Kangawa K \& Matsuo H 1990 Neuromedin U-like immunoreactivity in rat intestine: regional distribution and immunohistochemical study. Neuropeptides 15 1-9.

Howard AD, Wang R, Pong SS, Mellin TN, Strack A, Guan XM, Zeng Z, Williams DL Jr, Feighner SD, Nunes CN et al. 2000 Identification of receptors for neuromedin $\mathrm{U}$ and its role in feeding. Nature 406 70-74.

Ivanov TR, Lawrence CB, Stanley PJ \& Luckman SM 2002 Evaluation of neuromedin $\mathrm{U}$ actions in energy homeostasis and pituitary function. Endocrinology 143 3813-3821. 
Janssen PA, Niemegeers CJE \& Dony JGH 1963 The inhibitory effect of fentanyl and other morphine-like analgesics on the warm water induced tail withdrawal reflex. Arzneimittelforschung 13 502-507.

Kage R, O'Harte F, Thim L \& Conlon JM 1991 Rabbit neuromedin U-25: lack of conservation of a posttranslational processing site. Regulatory Peptides 33 191-198.

Klein SL, Kriegsfeld LJ, Hairston JE, Rau V, Nelson RJ \& Yarowsky PJ 1996 Characterization of sensorimotor performance, reproductive and aggressive behaviors in segmental trisomic 16 (Ts65Dn) mice. Physiology and Behavior 60 1159-1164.

Kojima M, Haruno R, Nakazato M, Date Y, Murakami N, Hanada R, Matsuo H \& Kangawa K 2000 Purification and identification of neuromedin $U$ as an endogenous ligand for an orphan receptor GPR66 (FM3). Biochemical and Biophysical Research Communications 276 435-438.

Kowalski TJ, Houpt TA, Jahng J, Okada N, Chua SC Jr \& Smith GP 1998 Ontogeny of neuropeptide $\mathrm{Y}$ expression in response to deprivation in lean Zucker rat pups. American Journal of PhysiologyRegulatory, Integrative and Comparative Physiology 275 R466-R470.

Lalonde R, Botez MI, Bontemps R \& Loron P 1994 Effects of an ectodermal microceptor preparation on motor coordination in cerebellar mutant mice. Pharmacology, Biochemistry and Behavior 49 777-779.

Lalonde R, Joyal CC \& Beaudin S 1997 Effects of sodium azide on motor activity, motor coordination, and learning. Pharmacology, Biochemistry and Behavior 56 67-71.

Lira SA, Kinloch RA, Mortillo S \& Wassarman PM 1990 An upstream region of the mouse ZP3 gene directs expression of firefly luciferase specifically to growing oocytes in transgenic mice. PNAS 87 7215-7219.

Lo G, Legon S, Austin C, Wallis S, Wang Z \& Bloom SR 1992 Characterization of complementary DNA encoding the rat neuromedin U precursor. Molecular Endocrinology 6 1538-1544.

Maggi CA, Patacchini R, Giuliani S, Turini D, Barbanti G, Rovero P \& Meli A 1990 Motor response of the human isolated small intestine and urinary bladder to porcine neuromedin U-8. British Journal of Pharmacology 99 186-188.

Malendowicz LK, Nussdorfer GG, Markowska A, Tortorella C, Nowak M \& Warchol JB 1994 Effects of neuromedin U (NMU)-8 on the rat hypothalamo-pituitary-adrenal axis. Evidence of a direct effect of NMU-8 on the adrenal gland. Neuropeptides 26 47-53.

Mann JR \& McMahon AP 1993 Factors influencing frequency production of transgenic mice. Methods in Enzymology 225 771-781.

Minamino N, Kangawa K \& Matsuo H 1985a Neuromedin U-8 and U-25: novel uterus stimulating and hypertensive peptides identified in porcine spinal cord. Biochemical and Biophysical Research Communications 130 1078-1085.

Minamino N, Sudoh T, Kangawa K \& Matsuo H 1985 b Neuromedins: novel smooth-muscle stimulating peptides identified in porcine spinal cord. Peptides 3 245-248.

Mondal MS, Date Y, Murakami N, Toshinai K, Shimbara T, Kangawa K \& Nakazato M 2003 Neuromedin U acts in the central nervous system to inhibit gastric acid secretion via CRH system. American Journal of Physiology - Gastrointestinal and Liver Physiology 284 G963-G969.

Nakahara K, Hanada R, Murakami N, Teranishi H, Ohgusu H, Fukushima N, Moriyama M, Ida T, Kangawa K \& Kojima M 2004 The gut-brain peptide neuromedin $\mathrm{U}$ is involved in the mammalian circadian oscillator system. Biochemical and Biophysical Research Communications 318 156-161.
Nakazato M, Hanada R, Murakami N, Date Y, Mondal MS, Kojima M, Yoshimatsu H, Kangawa K \& Matsukura S 2000 Central effects of neuromedin $\mathrm{U}$ in the regulation of energy homeostasis. Biochemical and Biophysical Research Communications 277 191-194.

Niimi M, Murao K \& Taminato T 2001 Central administration of neuromedin $\mathrm{U}$ activates neurons in ventrobasal hypothalamus and brainstem. Endocrine 16 201-206.

Nutt DJ, Taylor SC \& Little HJ 1986 Optimizing the pentetrazol infusion test for seizure threshold measurement. Journal of Pharmacy and Pharmacology 38 697-698.

O'Harte F, Bockman CS, Abel PW \& Conlon JM 1991 Isolation, structural characterization and pharmacological activity of dog neuromedin U. Peptides 12 11-15.

Okabe M, Ikawa M, Kominami K, Nakanishi T \& Nishimune Y 1997 'Green mice' as a source of ubiquitous green cells. FEBS Letters 407 313-319.

Raddatz R, Wilson AE, Artymyshyn R, Bonini JA, Borowsky B, Boteju LW, Zhou S, Kouranova EV, Nagorny R, Guevarra MS et al. 2000 Identification and characterization of two neuromedin $\mathrm{U}$ receptors differentially expressed in peripheral tissues and the central nervous system. Journal of Biological Chemistry 275 32452-32459.

Redrobe JP \& Bourin M 1998 Dose-dependent influence of buspirone on the activities of selective serotonin reuptake inhibitors in the mouse forced swimming test. Psychopharmacology 138 198-206.

Rogers DC, Jones DN, Nelson PR, Jones CM, Quilter CA, Robinson TL \& Hagan JJ 1999 Use of SHIRPA and discriminant analysis to characterise marked differences in the behavioural phenotype of six inbred mouse strains. Behavioural Brain Research 105 207-217.

Schreiber S, Backer MM, Yanai J \& Pick CG 1996 The antinociceptive effect of fluvoxamine. European Neuropsychopharmacology 6 281-284.

Shan L, Qiao X, Crona JH, Behan J, Wang S, Laz T, Bayne M, Gustafson EL, Monsma FJ Jr \& Hedrick JA 2000 Identification of a novel neuromedin $U$ receptor subtype expressed in the central nervous system. Journal of Biological Chemistry 275 39482-39486.

Steru L, Chermat R, Thierry B \& Simon P 1985 The tail suspension test: a new method for screening antidepressants in mice. Psychopharmacology 85 367-370.

Sumi S, Inoue K, Kogire M, Doi R, Takaori K, Suzuki T, Yajima H \& Tobe T 1987 Effect of synthetic neuromedin U-8 and U-25, novel peptides identified in porcine spinal cord, on splanchnic circulation in dogs. Life Sciences 41 1585-1590.

Tinsley FC, Taicher GZ \& Heiman ML 2004 Evaluation of a quantitative magnetic resonance method for mouse whole body composition analysis. Obesity Research 12 150-160.

Varty GB, Walters N, Cohen-Williams M \& Carey GJ 2001 Comparison of apomorphine, amphetamine and dizocilpine disruptions of prepulse inhibition in inbred and outbred mice strains. European Journal of Pharmacology 424 27-36.

Westfall TD, McCafferty GP, Pullen M, Gruver S, Sulpizio AC, Aiyar VN, Disa J, Contino LC, Mannan IJ \& Hieble JP 2002 Characterization of neuromedin $\mathrm{U}$ effects in canine smooth muscle. Journal of Pharmacology and Experimental Therapy 301 987-992.

Wren AM, Small CJ, Abbott CR, Jethwa PH, Kennedy AR, Murphy KG, Stanley SA, Zollner AN, Ghatei MA \& Bloom SR 2002 Hypothalamic actions of neuromedin U. Endocrinology 143 4227-4234.

Received in final form 5 January 2005

Accepted 18 January 2005 